Int. J. Dev. Biol. 52: 287-293 (2008)

doi: $10.1387 /$ ijdb.072333ag

\title{
Gene mapping of sperm quality parameters in recombinant inbred strains of mice
}

\author{
ANIELA GOLAS*, ANNA DZIEZA, KATARZYNA KUZNIARZ and JOZEFA STYRNA \\ Department of Genetics and Evolution, Institute of Zoology, Jagiellonian University, Krakow, Poland
}

\begin{abstract}
The aim of this study was to map chromosomal regions containing hypothetical genes responsible for the following parameters of mouse semen quality: (1) the percentage of sperm with abnormal head morphology, (2) the level of dead spermatozoa, (3) the percentage of sperm tails with residual cytoplasmic droplets, and (4) the percentage of sperm with impaired sperm tail membrane integrity. We also analyzed any possible correlations between these parameters. The most appropriate animal model for mapping genes controlling quantitative traits (QTL, quantitative trait locus) is a set of recombinant inbred (RI) strains. The set of $R I$ strains used in this study was derived from crosses between two inbred mouse strains, $\mathrm{KE}$ and CBA/Kw, which differ significantly in fertility parameters and gamete quality. We analyzed the four parameters of sperm quality in male mice from two parental strains and from $12 \mathrm{RI}$ strains. The strain distribution pattern (SDP) of 187 polymorphic microsatellite markers was prepared for 20 chromosomes of the mouse genome in 12 RI strains. We correlated the SDP of these markers with the values of sperm quality parameters, using MapManager QTX software (ver. b18). The mapping procedure indicated that the percentage of sperm with abnormal head morphology is controlled by gene(s) located in chromosomal regions 11q24, 11q31 and 6q15.6. There was also a strong correlation between male body weight and the hypothetical gene(s) in chromosomal region 18q47. A detailed analysis of the genes located in these regions enabled us to prepare a list of candidate genes. We discuss the basis of the correlation between the measured parameters.
\end{abstract}

KEY WORDS: gene mapping, mouse, sperm quality

\section{Introduction}

About $13-25 \%$ of human couples cannot conceive (Matzuk and Lamb, 2002; Olds-Clarke, 2003; Frey and Patel, 2004; Nayernia et al., 2004; Rajeev and Reddy, 2004), and approximately half of these cases are due to male fertility problems (Brugh and Lipshultz, 2004; Nayernia et al., 2004; Nikpoor et al., 2004). Spermatogenesis in mammals is regulated by genes located on the $Y$ chromosome (Krzanowska, 1969; Burgoyne, 1998), and by autosomal genes such as CFTR (Foppiani et al., 2004) or genes coding for androgens, estrogens and their receptors (Robertson etal., 1999; Henderson and Robaire, 2005; Huhtaniemi 2006). Genetic causes are considered the main factor responsible for as much as $30 \%$ of human infertility (Nayernia et al., 2003), but knowledge of the genes controlling human sperm quality is poor (Nikpoor et al., 2004; Vogt, 2004).

Recombinant inbred (RI) strains of mice (Bailey, 1971; Taylor, 1978) allow mapping of the genes controlling quantitative traits
(QT) (Silver, 1995; Williams et al., 2001; Broman, 2005). In our department we maintain $\mathrm{KE}$ and $\mathrm{CBA} / \mathrm{Kw}$ strains of mice, which differ in gamete quality and fertility parameters (Krzanowska, 1970; Krzanowska, 1976; Kaleta, 1977; Styrna and Krzanowska, 1995). A set of $12 \mathrm{RI}$ strains was developed from these two progenitor strains. We used this animal model to map chromosomal regions containing genes coding for four mouse semen quality parameters that are also evaluated during semen analysis in humans: percentage of sperm head abnormalities, level of dead spermatozoa, percentage of sperm with residual cytoplasmic droplets (which determines the degree of sperm cell maturity), and the integrity of the sperm tail cytoplasmic membrane.

To obtain the complete marker map in $12 \mathrm{RI}$ strains we analyzed polymorphic microsatellite sequences. We used MapManager QTX (ver. b18; Manly et al., 2001) to search for the

Abbreviations used in this paper: HOS, hypoosmotic (test), QTL, quantitative trait locus; RI, recombinant inbred (strain); SDP, strain distribution pattern.

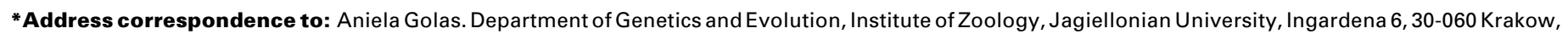
Poland. Fax: 48-012-634-2716. e-mail: aniela.golas@uj.edu.pl
} 
similarities between the strain distribution patterns (SDP) of these markers and the distribution of the measured parameters' values. This procedure enabled us to determine the most probable location of the QTL (quantitative trait locus) controlling these parameters. Further work is required to determine whether and how the candidate genes located in the mapped regions regulate gamete quality. The correlations between the analyzed parameters are discussed here. These are new results on genetic control of semen quality parameters in mice. The model should be useful in gaining an understanding of genetically based human infertility.

\section{Results}

\section{Microsatellite sequence analysis}

Of the 323 microsatellite sequences analyzed in 20 chromosomes of the mouse genome, 187 showed differences in PCR product length between the two progenitor inbred mouse strains, $\mathrm{KE}$ and $\mathrm{CBA} / \mathrm{Kw}$. These polymorphic sequences were further analyzed in order to prepare SDPs for $12 \mathrm{RI}$ strains $(\mathrm{RI} 5,6,17$, $21,29,40,41,42,43,44,47,49)$. The average distance between two consecutive markers on the chromosomes was $7.6 \mathrm{cM}$.

\section{Analysis of mouse semen quality parameters}

Table 1, 2 and 3 show the average values of the measured parameters, standard deviations (+/-SD), and the statistical significance $(p<0.05)$ of between-strain differences.

The body mass of the tested males showed little variation in the analyzed strains. The body mass of three $R I$ strains $(R I 21,29,43)$ was significantly lower than that of both progenitor strains. Testis weights of $\mathrm{KE}$ and $\mathrm{CBA} / \mathrm{Kw}$ males differed significantly $(\mathrm{p}<0.05)$, and this parameter showed segregation in all $12 \mathrm{RI}$ tested. The percentage of live spermatozoa was low in all analyzed strains. The males of only two RI strains (RI 41 and $R \mid 47$ ) had significantly less live sperm than both parental strains (Table 1).

The values of all five types of sperm head morphology significantly differed between the two progenitor strains. The total percentage of sperm head abnormalities was higher in KE males. These parameters revealed strong segregation in all $12 \mathrm{RI}$ strains
TABLE 1

\begin{tabular}{|c|c|c|c|}
\hline Inbred strains & $\begin{array}{l}\text { Body mass }(g) \\
(+/-S D)\end{array}$ & $\begin{array}{l}\text { Testis weight (g) } \\
\text { (+/-SD) }\end{array}$ & $\begin{array}{l}\text { Alive spermatozoa in } \\
\text { eosin test }(\%)(+/- \text { SD) }\end{array}$ \\
\hline $\mathrm{KE}$ & $27.9+/-2.9$ & $0.207+/-0.024 \mathrm{~b}$ & $32.7+/-5.7$ \\
\hline $\mathrm{CBA} / \mathrm{Kw}$ & $28.1+/-2.8$ & $0.140+/-0.015^{a}$ & $33.3+/-6.5$ \\
\hline RI 5 & $28.2+/-2.1$ & $0.120+/-0.007 \mathrm{ab}$ & $36.2+/-2.7$ \\
\hline RI 6 & $27.0+/-3.8$ & $0.159+/-0.027$ a & $29.4+/-4.8$ \\
\hline RI 17 & $26.6+/-3.3$ & $0.184+/-0.017^{a b}$ & $34.9+/-7.6$ \\
\hline $\mathrm{RI} 21$ & $21.2+/-2.5$ a b & $0.178+/-0.044^{b}$ & $33.0+/-7.3$ \\
\hline RI 29 & $21.7+/-2.1$ a b & $0.141+/-0.018^{a}$ & $35.1+/-3.2$ \\
\hline $\mathrm{RI} 40$ & $30.1+/-3.4$ & $0.161+/-0.009 \mathrm{ab}$ & $32.5+/-3.5$ \\
\hline $\mathrm{RI} 41$ & $26.8+/-1.8$ & $0.164+/-0.013 \mathrm{ab}$ & $23.0+/-6.1$ a b \\
\hline RI 42 & $27.8+/-2.1$ & $0.161+/-0.01 a b$ & $29.5+/-4.1$ \\
\hline $\mathrm{RI} 43$ & $23.8+/-3.0 \mathrm{ab}$ & $0.175+/-0.024$ a b & $30.2+/-4.6$ \\
\hline $\mathrm{RI} 44$ & $29.2+/-4.1$ & $0.129+/-0.012^{a}$ & $35.2+/-13.4$ \\
\hline RI 47 & $26.4+/-4.9$ & $0.123+/-0.021$ a & $21.0+/-7.2$ a b \\
\hline RI 49 & $26.2+/-3.1$ & $0.168+/-0.012^{a b}$ & $30.1+/-7.8$ \\
\hline
\end{tabular}

The results of body mass, testis weight and eosin test analysis in both parental strains (KE and $\mathrm{CBA} / \mathrm{Kw}$ ) and in $12 \mathrm{RI}$ strains of mice. The average values and the standard deviation (SD) values are presented. Statistically significant differences between tested strain and (a) KE strain and (b) $\mathrm{CBA} / \mathrm{Kw}$ strain are also indicated.

tested (Table 2).

The KE and CBA/Kw strains did not differ significantly in the percentage of sperm with a distal droplet or proximal droplet, nor in the number of sperm without residual droplets. These parameters showed weak segregation in the analyzed RI males, with proximal droplet level being the most varied characteristic (Table 3). Hypoosmotic tests showed the two progenitor strains to differ significantly in the percentage of sperm with broken tails and sperm with slightly bent tails. Males of the RI strains showed moderate segregation of four classes of sperm tail membrane integrity (Table 3).

Pearson's correlation coefficient ( $l$ ) was statistically significant for the percentage of sperm with abnormal head morphology and the percentage of live sperm $(p<0.05, r=-0.57)$. The percentage of sperm with slightly bent tails in the HOS test $(r=0.56)$ and testis weight $(r=0.55)$ were also correlated with the level of sperm head abnormality. The percentage of live sperm and the number of

TABLE 2

\begin{tabular}{|c|c|c|c|c|c|c|}
\hline \multirow[b]{2}{*}{ Inbred strains } & \multicolumn{5}{|c|}{ The level of the five classes of the abnormal sperm head morphology in all inbred strains testes (\%) (+/- SD) } & \multirow{2}{*}{$\begin{array}{l}\text { Total abnormal sperm } \\
\text { heads level }(\%)(+/- \text { SD) }\end{array}$} \\
\hline & class 1 & class 2 & class 3 & class 4 & polyploid cells & \\
\hline KE & $1.01+/-1.23 b$ & $11.12+/-3.15^{b}$ & $5.89+/-1.82^{b}$ & $2.66+/-1.38^{b}$ & $0.00^{b}$ & $20.3+/-4.0^{b}$ \\
\hline $\mathrm{CBA} / \mathrm{Kw}$ & $0.31+/-0.48^{a}$ & $2.19+/-0.93^{a}$ & $2.84+/-1.21^{a}$ & $1.13+/-0.66^{a}$ & $0.15+/-0.23^{a}$ & $6.6+/-1.9^{a}$ \\
\hline RI 5 & $0.21+/-0.49 a^{a}$ & $2.58+/-1.05^{a}$ & $1.56+/-0.80 \mathrm{ab}$ & $1.66+/-0.84$ ab & $0.03+/-0.11^{b}$ & $6.0+/-1.9^{a}$ \\
\hline RI 6 & $0.20+/-0.26^{a}$ & $3.87+/-1.48 a b$ & $4.01+/-1.04^{a}$ & $3.13+/-0.94 b$ & $1.07+/-0.71 \mathrm{ab}$ & $12.3+/-1.9 \mathrm{ab}$ \\
\hline RI 17 & $0.92+/-1.85$ & $4.62+/-2.52 \mathrm{ab}$ & $4.43+/-2.37 \mathrm{ab}$ & $1.72+/-1.21^{a}$ & $0.00^{b}$ & $11.7+/-3.1 \mathrm{ab}$ \\
\hline RI 21 & $2.03+/-1.86^{b}$ & $2.21+/-1.35^{b}$ & $7.36+/-3.40^{b}$ & $2.37+/-1.22^{b}$ & $0.00^{b}$ & $13.3+/-3.2 \mathrm{ab}$ \\
\hline RI 29 & $0.20+/-0.19$ & $2.39+/-1.01^{a}$ & $3.51+/-1.33^{a}$ & $1.51+/-0.93^{a}$ & $0.21+/-0.34^{a}$ & $7.8+/-2.4^{a}$ \\
\hline RI 40 & $0.25+/-0.41^{a}$ & $3.26+/-1.07 a b$ & $3.21+/-1.57^{a}$ & $1.10+/-0.64{ }^{a}$ & $0.08+/-0.22$ & $7.9+/-2.2^{a}$ \\
\hline RI 41 & $0.25+/-0.62^{a}$ & $2.74+/-1.02^{a}$ & $2.11+/-0.94 a b$ & $2.10+/-1.00^{b}$ & $1.03+/-0.81 \mathrm{ab}$ & $8.2+/-1.8^{a b}$ \\
\hline RI 42 & $0.40+/-0.52$ & $3.59+/-1.52 a b$ & $4.29+/-1.44 a b$ & $0.91+/-0.44 b$ & $0.12+/-0.32$ & $9.3+/-2.4$ ab \\
\hline RI 43 & $0.33+/-0.51^{a}$ & $5.98+/-1.85 \mathrm{ab}$ & $4.25+/-1.58 \mathrm{ab}$ & $3.16+/-1.78^{b}$ & $0.04+/-0.12$ & $13.8+/-3.1 \mathrm{ab}$ \\
\hline RI 44 & $0.38+/-0.47$ & $1.88+/-0.92 a^{a}$ & $3.42+/-0.84$ a & $1.20+/-0.75$ a & $0.20+/-0.34$ a & $7.1+/-1.6^{a}$ \\
\hline RI 47 & $0.51+/-0.38$ & $4.90+/-1.78$ a b & $6.29+/-1.63^{b}$ & $1.63+/-0.99$ a & $1.31+/-0.88 \mathrm{ab}$ & $14.6+/-2.9^{b}$ \\
\hline RI 49 & $0.68+/-0.60$ & $4.74+/-1.64 \mathrm{ab}$ & $4.67+/-1.77^{b}$ & $1.77+/-0.80 \mathrm{ab}$ & $0.15+/-0.22^{a}$ & $12.0+/-3.1 \mathrm{ab}$ \\
\hline
\end{tabular}


between tested strain and KE strain (a) and CBA/Kw strain (b) are also indicated. 
A

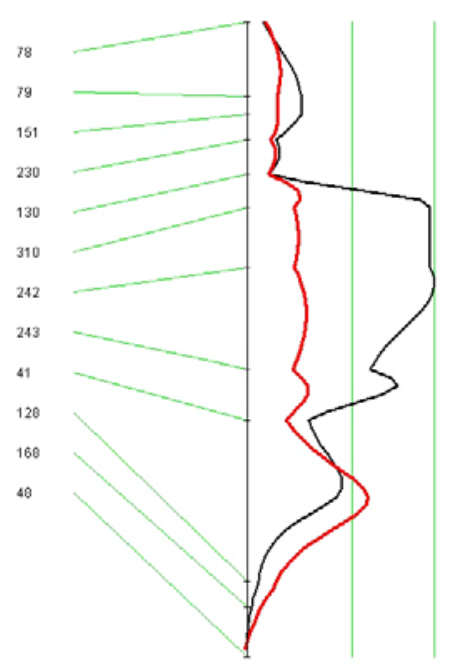

B

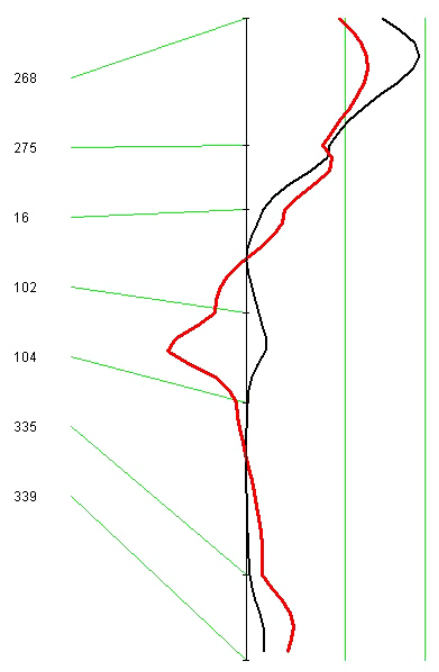

C

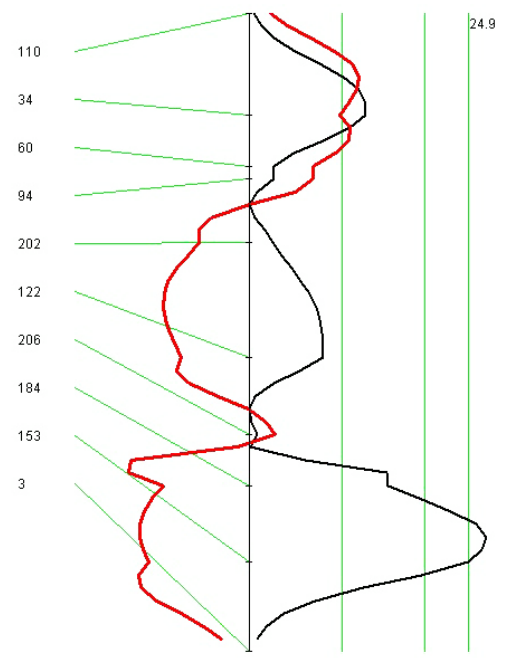

Fig. 1. The mapping results of sperm head abnormality percentage on chromosome 11(A) and on the chromosome 6 (B), and the results of male mice body mass gene mapping on chromosome 18 (C) are show.

sperm with swollen tails in the HOS test correlated positively $(r=0.64)$.

The results of the mapping procedure are shown in Table 4, presenting the correlations obtained from the marker regression procedure that are statistically significant at $p<0.001$. The interval mapping procedure revealed two chromosomal regions that correlate significantly ( $p<0.05$ for the whole genome scan) with the percentage of abnormal sperm head morphology, and one chromosomal region highly correlated with the body mass of the tested males. These chromosomal regions were searched for candidate genes possibly responsible for these two parameters.

Chromosomal region 11q24-11q31 (54-69Mpz; Fig. 1A) correlated with the percentage of abnormal sperm head morphology; it contains, for example, the Sparc gene controlling testis development. The products of Kif3a and Tekt3 genes located in this region are known to be functionally related to microtubules. Other genes coding for histone 3 subunits (Hist3h2ba, Hist3h2bb, Hist3h2a), and the Aurkb gene which is expressed in diplotene spermatogonia, are also located in the 11q24-11q31 region. Abnormal sperm head morphology also correlated strongly with chromosomal region 6q15.6 (34-45Mpz; Fig. 1B). In this region are two genes (Hipk2, Casp2) related to Trp53-dependent apoptosis.

Chromosomal region 18q41-18q47 (66.9-74.9Mpz; Fig. 1C) correlated with the body mass of the analyzed males; it contains a number of genes related to metabolism. One of them is Lipg coding for lipase, and another is Acaa2 whose protein product is responsible for lipid metabolism in mitochondria. The protein product of Cidea is related to elevated metabolism and lipolysis. Cholesterol binding and transport is mediated by the protein

TABLE 3

\begin{tabular}{|c|c|c|c|c|c|c|c|}
\hline \multirow[b]{2}{*}{ Inbred strain } & \multicolumn{3}{|c|}{$\begin{array}{l}\text { The level of sperms with/without the cytoplasmic } \\
\text { residual droplet }(\%)(+/- \text { SD) }\end{array}$} & \multicolumn{4}{|c|}{$\begin{array}{l}\text { The level of sperm tails revealing four different shapes } \\
\text { in hypotonic suspension }(\%)(+/- \text { SD) }\end{array}$} \\
\hline & proximal droplet & distal droplet & without droplet & straight tails & slightly bent tails & broken tails & swollen tails \\
\hline KE & $3.20+/-1.47$ & $84.45+/-2.22$ & $12.35+/-2.04$ & $34.76+/-5.13$ & $13.90+/-3.77^{b}$ & $4.07+/-1.38^{b}$ & $47.27+/-6.60$ \\
\hline $\mathrm{CBA} / \mathrm{Kw}$ & $4.46+/-2.41$ & $84.74+/-6.56$ & $10.80+/-5.68$ & $32.68+/-5.75$ & $9.86+/-3.30^{a}$ & $8.26+/-3.29$ a & $49.20+/-9.83$ \\
\hline RI 5 & $1.48+/-0.63 a b$ & $84.60+/-2.13$ & $13.92+/-2.23$ & $21.54+/-6.29$ a b & $7.22+/-3.68^{a}$ & $16.53+/-5.92 \mathrm{ab}$ & $54.70+/-7.38$ \\
\hline RI 6 & $1.99+/-1.10^{b}$ & $78.31+/-4.00$ & $19.70+/-4.60$ a b & $33.63+/-18.80$ & $15.17+/-6.38$ & $3.77+/-4.60$ & $47.43+/-10.99^{b}$ \\
\hline RI 17 & $2.26+/-1.43^{b}$ & $85.28+/-5.01$ & $12.46+/-3.79$ & $28.11+/-9.87$ & $6.34+/-2.87$ a b & $5.73+/-3.46$ & $59.83+/-9.40$ a b \\
\hline RI 21 & $3.63+/-1.53$ & $82.63+/-3.00$ & $13.74+/-2.73$ & $24.55+/-5.02 \mathrm{ab}$ & $11.35+/-4.02$ & $7.49+/-6.21$ & $56.61+/-11.56$ \\
\hline RI 29 & $2.65+/-0.57$ & $86.08+/-2.77$ & $11.28+/-2.36$ & $37.55+/-4.64$ & $4.38+/-0.85$ a b & $3.73+/-1.86^{b}$ & $54.35+/-4.77$ \\
\hline RI 40 & $10.65+/-3.98 \mathrm{ab}$ & $81.88+/-5.64$ & $7.48+/-2.07^{a}$ & $38.59+/-8.45$ & $4.64+/-3.07$ a b & $2.43+/-1.37 \mathrm{ab}$ & $54.35+/-9.06$ \\
\hline RI 41 & $2.74+/-1.05$ b & $82.90+/-4.61$ & $14.36+/-5.22$ & $45.15+/-6.67 \mathrm{ab}$ & $9.79+/-3.96$ & $9.84+/-4.54$ a & $35.23+/-9.54 \mathrm{ab}$ \\
\hline RI 42 & $10.09+/-4.74$ a b & $74.95+/-6.35 \mathrm{ab}$ & $14.96+/-7.04$ & $31.05+/-7.56$ & $10.53+/-4.61$ & $8.94+/-6.57$ & $49.49+/-11.83$ \\
\hline RI 43 & $0.53+/-0.60 \mathrm{ab}$ & $90.73+/-2.42 \mathrm{ab}$ & $8.75+/-2.17^{a}$ & $34.06+/-9.31$ & $7.57+/-2.27^{a}$ & $1.14+/-0.77 \mathrm{ab}$ & $57.23+/-8.04$ a \\
\hline RI 44 & $1.47+/-1.01 \mathrm{ab}$ & $90.87+/-3.34 \mathrm{ab}$ & $7.67+/-3.07^{a}$ & $25.03+/-8.71^{a}$ & $11.81+/-5.68$ & $7.80+/-7.00$ & $55.36+/-14.02$ \\
\hline RI 47 & $3.66+/-1.17$ & $81.80+/-4.18$ & $14.54+/-5.25$ & $40.39+/-16.20$ & $22.13+/-10.60^{b}$ & $3.76+/-3.58^{b}$ & $33.73+/-12.28^{a}$ \\
\hline RI 49 & $2.05+/-1.04^{b}$ & $89.27+/-3.23$ a & $8.68+/-3.23$ a & $26.02+/-7.82^{a}$ & $7.83+/-5.37^{\mathrm{a}}$ & $13.16+/-7.30^{a}$ & $52.99+/-14.16$ \\
\hline
\end{tabular}

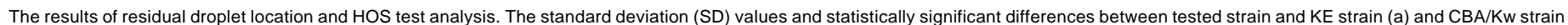
(b) are also indicated. 
product of Stard6, which is in chromosomal region 18q41-18q47. That region also contains Mc4r. Mice with a disrupted Mc4rgene show abnormal leptin function and obesity.

\section{Discussion}

Mapping the genes responsible for mouse sperm quality can aid our understanding of the molecular mechanisms underlying the regulation of human sperm quality. Reproductive development and physiology are conserved in mammal evolution; this makes mouse models useful in studies of human fertility. We hope our work leads to the development of simple molecular tests to analyze the genetic causes of human infertility.

The aim of this study was to map chromosomal regions controlling four parameters of mouse sperm quality: head morphology, the level of live spermatozoa, sperm maturity, and the integrity of the sperm tail cytoplasmic membrane. We also estimated the correlations between the analyzed parameters.

The results show that sperm head morphology is controlled by a gene or genes in chromosomal region 11q24-11q31. It has been suggested that abnormal organization of the cytoskeleton during sperm maturation is partially responsible for teratozoospermy (Tachibana et al., 2005). One of the candidate genes from the mapped region 11q24-11q31 is a gene related to the function of microtubules in spindle formation (Kif3, kinesin family member 3A; Haraguchi et al., 2006), and the other is Tekt3 (tektin 3), coding for a microtubule-associated cytoskeletal protein expressed in mouse pachytene spermatocytes and early round spermatids (Roy et al., 2004). Other genes found in this region, Hist3h2ba, Hist3h2bb and Hist3h2a (histone 3, H2ba, H2bb, H2a), are responsible for histone 3 activity and function. The protein product of Aurkb, aurora kinase B, which is active before histone phosphorylation (Parra et al., 2003), influences chromosome segregation in male meiosis (Tang et al., 2006) and is responsible for an increased level of abnormal sperm head morphology (Chemes and Rawe, 2003). Another candidate gene in region 11q24-11q31 is Sparc, coding for a secreted acidic cysteine-rich glycoprotein which may influence the formation of abnormal spermatozoa due to its role in the regulation of embryonic testis development (Wilson et al., 2006).

It is believed that abnormalities in the shape of the sperm head have low specificity; that is, similar abnormalities (although occurring at different frequencies) can be found in normal (especially in prepubescent) males, and in males treated with mutagens. Such abnormalities may result either from the activity of a mutagen or as an effect of an adverse microenvironment in the gonad. The pleiotropic effects of most mutations indicate that they may be related to the function of genes involved in the production of proteins regulating the basic functions of the cell (housekeeping genes), which may be particularly important during spermatogenesis.

The mapping procedure we used allowed us to locate another chromosomal region, $6 q 15.6$, related to the morphology of the sperm head. The protein products of two genes located in this region (Hipk2 gene, homeodomain interacting protein kinase 2 and Casp2gene, caspase 2) control proliferation and apoptosis processes and thus may participate in the elimination of abnormal cells during spermatogenesis. Several genes located in the mapped region code for vomeronasal receptors. Male germ cells have been shown to express some of the genes active in olfactory pathways (Defer et al., 1998). Possibly the role of olfactory receptors extends far beyond their well known function in sperm

TABLE 4

\begin{tabular}{|c|c|c|c|c|c|c|c|c|c|c|}
\hline \multirow[b]{2}{*}{ Parameter } & \multicolumn{5}{|c|}{ Marker regression analysis } & \multirow{2}{*}{$\begin{array}{c}\text { Additive } \\
\text { effect }\end{array}$} & \multirow{2}{*}{$\begin{array}{c}\text { Peak } \\
\text { LRS value }\end{array}$} & \multicolumn{3}{|c|}{$\begin{array}{l}\text { Significance thresholds } \\
\text { for the peak LRS value }\end{array}$} \\
\hline & Marker & Locus & LRS & $\%$ & $\mathbf{p}$ & & & $p=0.63$ & $\mathrm{p}=0.05$ & $p=0.001$ \\
\hline \multirow{5}{*}{ sperms with abnormal head morphology (\%) } & D11Mit310 & $11 \mathrm{q} 24$ & 19.1 & 80 & 0.00001 & 5.11 & 19.5 & 10.9 & 19.6 & 24.7 \\
\hline & D11Mit242 & $11 q 31$ & 19.1 & 80 & 0.00001 & 5.11 & 19.5 & 10.9 & 19.6 & 24.7 \\
\hline & D13Mit3 & $13 q 10$ & 14.9 & 71 & 0.00011 & 5.07 & 14.9 & 10.8 & 19.7 & 27.0 \\
\hline & D6Mit268 & $6 q 15.6$ & 14.9 & 71 & 0.00011 & 5.07 & 18.9 & 10.8 & 19.5 & 26.1 \\
\hline & D8Mit289 & $8 q 11$ & 12.8 & 66 & 0.00035 & -4.95 & 12.8 & 10.8 & 19.4 & 25.1 \\
\hline \multirow{3}{*}{ sperms without cytoplasmic droplet (\%) } & D1 Mit452 & $1 \mathrm{q} 86.6$ & 13.4 & 67 & 0.00025 & -2.39 & 13.5 & 9.9 & 17.9 & 22.4 \\
\hline & D1Mit215 & $1 q 47$ & 12.2 & 64 & 0.00047 & -2.35 & 12.2 & 10.0 & 17.8 & 22.3 \\
\hline & D11Mit130 & $11 q 20$ & 11.2 & 61 & 0.00083 & 2.28 & 11.2 & 10.0 & 17.8 & 22.4 \\
\hline sperms with slightly bent tails (\%) & D15Mit252 & $15 q 15$ & 11.3 & 61 & 0.00079 & -4.21 & 12.1 & 9.1 & 22.5 & 33.7 \\
\hline \multirow{2}{*}{ sperms with broken tails (\%) } & D11Mit48 & $11 q 77$ & 11.5 & 62 & 0.0007 & 4.52 & 10.5 & 10.1 & 16.3 & 22.4 \\
\hline & D7Mit37 & $7 q 49.8$ & 12.4 & 64 & 0.00043 & 4.57 & 12.4 & 10.2 & 16.2 & 23.5 \\
\hline \multirow{5}{*}{ sperms with straight tails (\%) } & D13Mit147 & $13 q 49$ & 12.7 & 65 & 0.00036 & -3.8 & 12.7 & 10.0 & 17.7 & 26.2 \\
\hline & D1 Mit296 & $1 \mathrm{q} 8.3$ & 15.0 & 71 & 0.00011 & -3.75 & 15.0 & 10.0 & 17.5 & 23.1 \\
\hline & D6Mit102 & $6 q 38.5$ & 14.8 & 71 & 0.00012 & 3.72 & 14.8 & 10.1 & 17.7 & 26.7 \\
\hline & D11Mit79 & $11 q 10.9$ & 11.9 & 63 & 0.00057 & -3.51 & 12.2 & 10.0 & 17.6 & 26.7 \\
\hline & D11Mit151 & $11 q 13$ & 11.9 & 63 & 0.00057 & -3.51 & 12.2 & 10.0 & 17.6 & 26.7 \\
\hline \multirow{2}{*}{ Body mass (g) } & D18Mit153 & $18 q 47$ & 23.0 & 85 & 0.00000 & -2.77 & 24.9 & 9.8 & 18.4 & 23.0 \\
\hline & D19Mit10 & $19 q 47$ & 12.2 & 64 & 0.00048 & -2.2 & 14.1 & 9.8 & 18.2 & 24.5 \\
\hline
\end{tabular}

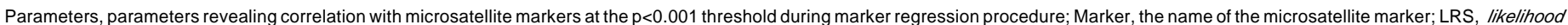

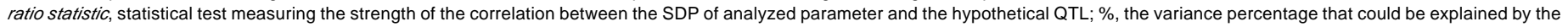

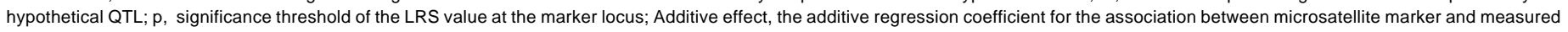

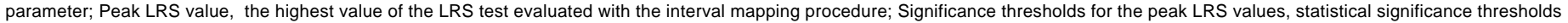
for the peak LRS value evaluated with the permutation test (for 5000 and with $1 \mathrm{cM}$ interval) in the whole genome scan. 
chemotaxis in the female reproductive tract and in the migration of primordial germ cells towards the gonads (Goto et al., 2001).

Mapping of the genes controlling body mass in mouse males showed that this parameter correlates with chromosomal region $18 q 41-18 q 47$, which is especially rich in candidate genes whose protein products are involved in lipid metabolism. For example, Lipg coding for lipase which regulates the HDL level, and Acaa2 encoding acetyl-Coenzyme A acyltransferase 2 (mitochondrial 3oxoacyl-Coenzyme A thiolase) which is connected with lipid metabolism in mitochondria, are both in this region. The protein product of another gene from this region (Cidea, cell deathinducing DNA fragmentation factor, alpha subunit-like effector A) plays a role in the regulation of the metabolism level in mitochondria and lipolysis, by regulating the function of the mitochondrial proton carrier protein (uncoupling protein 1) encoded by Ucp1 (Zhou et al., 2003). Region 18q41-18q47 also contains Stard6 (StAR-related lipid transfer (START) domain containing 6), whose protein product binds lipids and is involved in cholesterol transport. Stard6knockout mice are resistant to obesity (Soccio et al., 2002). The Mc4rgene (melanocortin 4 receptor) is also located in region $18 q 41-18 q 47$. Obesity due to abnormal metabolic rate and food intake was observed in Mc4r knockout mice (Chen et al., 2000).

Three measured parameters of semen quality - level of live spermatozoa, percentage of fully matured sperm, and sperm tail membrane integrity - showed no significant correlation with microsatellite markers. Because the differences between the parental strains are minimal for these traits, the genes controlling them do not segregate in the RI strains, and the mapping procedure cannot be applied. The parental strains differ significantly in testis weight, and segregation of this trait can be seen in all $12 \mathrm{RI}$ strains, but most of them have testis weights similar to that of the CBA/Kw parental strain. In only one $R I$ strain ( $R I 21)$, testis weight did not differ from that in the KE parental strain. This skewed trait segregation could have an effect on the mapping procedure. It is also possible that these four parameters are controlled by a large number of genes having weak influences on the parameters' values and that none of them can be mapped.

Pearson's correlation coefficients were calculated for the correlations between sperm quality parameters. A higher percentage of abnormal sperm head morphology correlated with higher testis weight. It may be that testis temperature increases with testis mass, impairing spermatogenesis. The level of sperm head abnormality correlated negatively with the percentage of live spermatozoa. This suggests the operation of processes eliminating some of the abnormal spermatozoa by apoptosis. There was a positive correlation between the level of live spermatozoa and the percentage of sperm with swollen tails (i.e., with proper tail membrane integrity) in the HOS test. This quality parameter might also be subject to processes that eliminate abnormal sperm.

Additional microsatellite sequence analyses of the mapped chromosomal regions are needed to obtain denser marker distributions. New RI strains are being developed in our department from KE and CBA/Kw parental strains. The parameters presented in this paper will be measured in these strains and added to the mapping procedure in order to decrease the chromosomal region intervals. These procedures should help shorten the candidate gene lists. The expression levels and sequencing of the chosen genes will be analyzed to confirm their role in regulating mouse sperm quality parameters. The results of this work should lead to the development of simple diagnostic molecular tests to determine human infertility causes, and new contraception methods for men.

\section{Materials and Methods}

\section{Mice mice}

The study used groups of 8-10 adult male mice (3-7 months) from two progenitor inbred mouse strains, $\mathrm{KE}$ and $\mathrm{CBA} / \mathrm{Kw}$, and from $12 \mathrm{RI}$ strains maintained in our department. Three RI strains were developed from crosses between CBA/Kw females and KE males (CBXE strains 17, 21, 29 ), and nine $R I$ strains were derived from reciprocal crosses between $K E$ females and CBA/Kw males (EXCB strains 5, 6, 40, 41, 42, 43, 44, 47, 49). All animals were given a standard pelleted diet (Labofeed B, Kcynia) and water ad libitum, and were kept under a 12L:12D conditions.

\section{Microsatellite sequence analysis}

A standard phenol-chloroform protocol was used to isolate genomic DNA from mouse tails. Microsatellite sequences were analyzed by PCR and electrophoresis to prepare a marker map of the mouse genome. Primer sequences were derived from the Jackson Laboratory database (www.jax.org). PCR was carried out in $15 \mu \mathrm{l}$ for 30-35 cycles with the following conditions (Biometra, T-gradient): $30 \mathrm{~s}$ at $94^{\circ} \mathrm{C}$, primer annealing for $30 \mathrm{~s}$ at temperature appropriate for the primer used, and $30 \mathrm{~s}$ of extension at $72^{\circ} \mathrm{C}$ with Taq polymerase (Finnzymes, Finland). PCR products were electrophoresed on $3.5 \%$ agarose gel stained with ethidium bromide. Only sequences showing length differences between the two progenitor strains were used for further studies, and to prepare their SDPs for 20 chromosomes of $12 \mathrm{RI}$ strains.

\section{Mouse semen quality parameter analysis.}

The animals were killed by cervical dislocation and weighed. Both testes were dissected and weighed. The content of both vas deferens was gently squeezed out directly into $100 \mu \mathrm{l}$ of M2 medium (Sigma-Aldrich, Germany), placed in small Petri dishes, and allowed to disperse at room temperature for 5 minutes.

\section{Sperm head morphology}

Smears prepared from $10 \mu$ l of sperm suspension were air-dried, fixed in a mixture of ethanol and acetic acid $(3: 1, \mathrm{v} / \mathrm{v})$, stained with $0.2 \%$ eosin $Y$ (Sigma-Aldrich, Germany) for 30 minutes, and observed by LM under a 100x immersion objective. For each smear, 300 sperm were analyzed. We classified sperm head shape into one of four sperm head abnormality types as described by Krzanowska (1976). All sperm characterized by increased sperm head size (presumably polyploidy) were put into an additional fifth abnormality class.

\section{Dead spermatozoa level (eosin test)}

Twenty $\mu \mathrm{l}$ of sperm suspension was mixed with $20 \mu \mathrm{l} 0.2 \%$ eosin $Y$ and incubated for 10 minutes on a microscope stage warmer (Japan) at $37^{\circ}$ C. Smears were air-dried and observed by LM under a 40x objective. For each smear, 350 sperm were analyzed. Sperm with red heads were classified as dead and those with green heads were classified as alive.

\section{Integrity of sperm tail cytoplasmic membrane (hypoosmotic test,} HOS)

Twenty $\mu$ l of sperm suspension was mixed with $100 \mu$ of sterile water (Sigma-Aldrich, Germany). Then $20 \mu \mathrm{l}$ of the diluted semen was placed on a microscope slide and incubated at $37^{\circ} \mathrm{C}$ on a microscope stage warmer for 5 minutes under a cover slip. For each smear about 400 spermatozoa were observed by LM under a $40 x$ objective, and classified according to tail shape in a hypotonic suspension as (a) straight, with defective integrity of the sperm cytoplasmic membrane, (b) slightly bent, 
(c) broken, and (d) swollen, with proper integrity of the sperm cytoplasmic membrane.

\section{Sperm tails with cytoplasmic residual droplets}

Thirteen $\mu \mathrm{l}$ of sperm suspension was observed by LM with a $40 \mathrm{x}$ objective. About 300 living sperm of each sample were analyzed and classified as (a) completely matured, without cytoplasmic droplets, (b) with distal cytoplasmic droplets, that is, droplets located at the end of the mitochondrial sheath, and (c) with proximal cytoplasmic droplets, that is, droplets located on the tail close to the sperm head.

\section{Statistical analysis}

After angle transformation of the percentage values of four measured parameters, the Student test at $p<0.05$ (equal variances) was applied. We used Pearson's correlation coefficient $(p<0.05)$ to find the relationships between the analyzed parameters.

The marker regression procedure was performed with MapManager QTX ver. b18 (Manly et al., 2001) to find microsatellite markers that are correlated (LRS test, likelihood ratio statistic) with the SDP of the analyzed parameters at $p<0.001$ using the Kosambi function (i.e., with the middle interference rate). Further analyses (interval mapping) were done to determine the most probable locus of the genes deemed to control these traits. Three statistical significance thresholds were estimated with a permutation test (5000 iterations) for the empirical probability of the relationship between the putative locus of the gene and the value of the trait: $p<0.63$ for suggestive correlation only, $p<0.05$ for a statistically significant correlation, and $\mathrm{p}<0.001$ for a highly significant correlation (Chmielewicz and Manly, 2002; Li et al., 2005).

Chromosomal regions showing LRS test values above the $p<0.05$ statistical significance threshold were searched in the mouse genome database (www.ncbi.nih.gov) to choose candidate genes for further analysis needed to confirm their role in controlling gamete quality in male mice.

\section{Acknowledgements}

This work was supported by DS/BINoZ/IZ/775/2006 and BW/IZ/4/ 2005 from the Institute of Zoology of the Jagiellonian University.

\section{References}

BAILEY, D.W. (1971) Recombinant-inbred strains. An aid to finding identity, linkage and function of histocompatibility and other genes. Transplantation 11: 325327.

BROMAN, K.W. (2005) The genomes of recombinant inbred lines. Genetics 169: 1133-1146.

BRUGH, V.M. $3^{\text {RD }}$ and LIPSHULTZ, L.I. (2004) Male factor infertility: evaluation and management. Med. Clin. North Am. 88(2): 367-385.

BURGOYNE, P.S. (1998) The role of Y-encoded genes in mammalian spermatogenesis. Semin. Cell Dev. Biol. 9: 423-432.

CHEMES, E.H. and RAWE, Y.V. (2003) Sperm pathology: a step beyond descriptive morphology. Origin, characterization and fertility potential of abnormal sperm phenotypes in infertile men. Hum. Reprod. Update 9(5): 405-428.

CHEN, A.S., MARSH, D.J., TRUMBAUER, M.E., FRAZIER, E.G., GUAN, X.M., YU, H., ROSENBLUM, C.I., VONGS, A., FENG, Y., CAO, L., METZGER, J.M., STRACK, A.M., CAMACHO, R.E., MELLIN, T.N., NUNES, C.N., MIN, W., FISHER, J., GOPAL-TRUTER, S., MACINTYRE, D.E., CHEN, H.Y. and VAN DER PLOEG, L.H. (2000) Inactivation of the mouse melanocortin-3 receptor results in increased fat mass and reduced lean body mass. Nat. Genet. 26(1): 97-102.

CHMIELEWICZ, K.M. and MANLY, K.F. (2002) User manual for QTX. Software for genetic mapping of Mendelian markers and quantitative trait loci. Revised for QTX b17. Roswell Park Center Institute.

DEFER, N., MARINX, O., POYARD, M., LIENARD, M.O., JEGOU, B. and HANOUNE, J. (1998) The olfactory adenylyl cyclase type 3 is expressed in male germ cells. FEBS Lett. 424(3): 216-220.
FOPPIANI, L., BAFFICO, M., LANDO, G., CAPPI, C., DE CASSAN, P., PATROSSO, M.C., VITALI, A., PENCO, S., GIUSTI, M. and MINUTO, F. (2004) Bilateral carcinoma in situ of the testis and cystic fibrosis transmembrane conductance regulator (CFTR) mutation in an azoospermic patient with late-onset 21 betahydroxylase deficiency. J. Endocrinol. Invest. 27(4): 370-374.

FREY, K.A. and PATEL, K.S. (2004) Initial evaluation and management of infertility by the primary care physician. Mayo Clin. Proc. 79(11): 1439-1443.

GOTO, T., SALPEKAR, A. and MONK, M. (2001) Expression of a testis-specific member of the olfactory receptor gene family in human primordial germ cells. Mol. Hum. Reprod. 7: 553-558.

HARAGUCHI, K., HAYASHI, T., JIMBO, T., YAMAMOTO, T. and AKIYAMA, T. (2006) Role of the kinesin-2 family protein, KIF3, during mitosis. J. Biol. Chem. 281(7): 4094-4099.

HENDERSON, N.A. and ROBAIRE, B. (2005) Effects of PNU157706, a dual 5alpha-reductase inhibitor, on rat epididymal sperm maturation and fertility. Biol. Reprod. 72(2): 436-443.

HUHTANIEMI, I. (2006) Mutations along the pituitary-gonadal axis affecting sexual maturation: Novel information from transgenic and knockout mice. Mol. Cell. Endocrinol. 254-255: 84-90.

KALETA, E. (1977) Influence of genetic factors on the fertilization of mouse ova in vitro. J. Reprod. Fert. 51: 375-381.

KRZANOWSKA, H. (1969) Factor responsible for spermatozoan abnormality located on the Y chromosome in mice. Genet. Res., Camb. 13: 17-24.

KRZANOWSKA, H. (1970) Relation between fertilization rate and penetration of eggs by supplementary spermatozoa in different mouse strains and crosses. J. Reprod. Fert. 22: 199-204.

KRZANOWSKA, H. (1976) Types of sperm-head abnormalities in four inbred strains of mice. Acta Biol. Cracov., Ser. Zoologia 19: 79-85.

LI, R., LYONS, M.A., WITTENBURG, H., PAIGEN, B. and CHURCHIL, G.A. (2005) Combining data from multiple inbred line crosses improves the power and resolution of QTL mapping. Genetics 169(3): 1699-1709.

MANLY, K.F., CUDMORE, R.H. JR. and MEER, J.M. (2001) Map Manager QTX, cross platform software for genetic mapping. Mamm. Genome 12: 930-932.

MATZUK, M.M., LAMB, D.J. (2002) Genetic dissection of mammalian fertility pathways. Nat. Cell Biol. 4, Suppl: 41-49.

NAYERNIA, K., MEINHARDT, A., DRABENT, B., ADHAM, I.M., MULLER, CH., STECKEL, M., SANCKEN, U. and ENGEL, W. (2003) Synergistic effects of germ cell expressed genes on male fertility in mice. Cytogenet. Genome Res. 103(3-4): 314-320.

NAYERNIA, K., LI M., JAROSZYNSKI, L., KHUSAINOV, R., WULF, G., SCHWANDT, I., KORABIOWSKA, M., MICHELMANN, H.W., MEINHARDT, A. and ENGEL, W. (2004) Stem cell based therapeutical approach of male infertility by teratocarcinoma derived germ cells. Hum. Mol. Genet. 13(14): 1451-1460.

NIKPOOR, P., MOWLA, J., MOVAHEDIN, S. and TIRAIHI, T. (2004) CatSpergene expression in postnatal development of mouse testis and in subfertile men with deficient sperm motility. Hum. Reprod. 19(1): 124-128.

OLDS-CLARKE, P. (2003) Unresolved issues in mammalian fertilization. Int. Rev. Cytol. 232: 129-184.

PARRA, M.T., VIERA, A., GOMEZ, R., PAGE, J., CARMENA, M., EARNSHAW, W.C., RUFAS J.S. and SUJA J.A. (2003) Dynamic relocalization of the chromosomal passenger complex proteins inner centromere protein (INCENP) and aurora-B kinase during male mouse meiosis. J. Cell Sci. 116(6): 961-974.

RAJEEV, S.K. and REDDY, K.V. (2004) Sperm membrane protein profiles of fertile and infertile men: identification and characterization of fertility-associated sperm antigen. Hum. Reprod. 19(2): 234-242.

ROBERTSON, K.M., O'DONNELL, L., JONES, M.E., MEACHEM, S.J., BOON, W.C., FISHER, C.R., GRAVES, K.H., MCLACHLAN, R.I. and SIMPSON, E.R. (1999) Impairment of spermatogenesis in mice lacking a functional aromatase (cyp 19) gene. Proc. Natl. Acad. Sci. USA 96(14): 7986-7991.

ROY, A., TAN, W., BURNS, K.H. and MATZUK, M.M. (2004) Tektin3 encodes an evolutionarily conserved putative testicular microtubules-related protein expressed preferentially in male germ cells. Mol. Reprod. Dev. 67(3): 295-302.

SILVER, L. (1995) Mouse genetics: concepts and practice. Oxford University Press, New York.

SOCCIO, R.E., ADAMS, R.M., ROMANOWSKY, M.J., SEHAYEK, E., BURLEY, 
S.K. and BRESLOW, J.L. (2002) The cholesterol-regulated StarD4 gene encodes a StAR-related lipid transfer protein with two closely related homologues, StarD5 and StarD6. Proc. Natl. Acad. Sci. USA 99(10): 6943-6948.

STYRNA, J. and KRZANOWSKA, H. (1995) Sperm select penetration test reveals differences in sperm quality in strains with different $Y$ chromosome genotype in mice. Arch. Androl. 53: 111-118.

TACHIBANA, M., TERADA, Y., MURAKAWA, H., MURAKAMI, T., YAEGASHI, N. and OKAMURA, K. (2005) Dynamic changes in the cytoskeleton during human spermiogenesis. Fert. Steril. 84, Suppl 2: 1241-1248.

TANG, C.J., LIN, C.Y. and TANG, T.K. (2006) Dynamic localization and functional implications of Aurora-C kinase during male mouse meiosis. Dev. Biol. 290(2): 398-410.

TAYLOR, B.A. (1978) Recombinant inbred strains: use in gene mapping. In: Origins of inbred mice. Morse H.C., eds.(Academic Press, NY): 423-438.

VOGT, P.H. (2004) Molecular genetics of human male infertility: from genes to new therapeutic perspectives. Curr. Pharm. Des. 10(5): 471-500.

WILLIAMS, R.W., GU, J., QI, S. and LU L. (2001) The genetic structure of recombinant inbred mice: high-resolution consensus maps for complex trait analysis. Genome Biol. 2(11): research0046.1-0046.18.

WILSON, M.J., BOWLES, J. and KOOPMAN, P. (2006) The matricellular protein SPARC is internalized in Sertoli, Leydig, and germ cells during testis differentiation. Mol. Reprod. Dev. 73(5): 531-539.

ZHOU, Z., YON TOH, S., CHEN, Z., GUO, K., NG, C.P., PONNIAH, S., LIN, S.C., HONG, W. and LI, P. (2003) Cidea-deficient mice have lean phenotype and are resistant to obesity. Nat. Genet. 35(1): 49-56.

\section{Related, previously published Int. J. Dev. Biol. articles}

See our recent Special Issue Developmental Biology in Poland edited by Kloc, Maleszewski and Tarkowski at: http://www.ijdb.ehu.es/web/contents.php?vol=52\&issue=2-3

See our Special Issue Mammalian Reproduction \& Development in honor of Anne McLaren and edited by Brigid Hogan at: http://www.ijdb.ehu.es/web/contents.php?vol=45\&issue=3

Fate of cranial neural crest cells during craniofacial development in endothelin-A receptor-deficient mice

Makoto Abe, Louis-Bruno Ruest and David E. Clouthier

Int. J. Dev. Biol. (2007) 51: 97-105

Early stages of neural crest ontogeny: formation and regulation of cell delamination

Chaya Kalcheim and Tal Burstyn-Cohen

Int. J. Dev. Biol. (2005) 49: 105-116

New views on retinal axon development: a navigation guide

Fanny Mann, William A. Harris and Christine E. Holt

Int. J. Dev. Biol. (2004) 48: 957-964

Human limb malformations; an approach to the molecular basis of development.

Karl-Heinz Grzeschik

Int. J. Dev. Biol. (2002) 46: 983-991

Conserved modularity and potential for alternate splicing in mouse and human Slit genes.

Melissa Little, Bree Rumballe, Kylie Georgas, Toshiya Yamada and Rohan D Teasdale

Int. J. Dev. Biol. (2002) 46: 385-391

Genetic architecture of leaf morphogenesis in Arabidopsis thaliana P Robles, JM Perez-Perez, H Candela, V Quesada, JM Barrero, S Jover-Gil, MR Ponce, JL Micol

Int. J. Dev. Biol. (2001) 45: S61-S62

Evidence that the rat osteopetrotic mutation toothless (tl) is not in the TNFSF11 (TRANCE, RANKL, ODF, OPGL) gene.

P R Odgren, N Kim, L van Wesenbeeck, C MacKay, A Mason-Savas, F F Safadi, S N Popoff, C Lengner, W van-Hul, Y Choi and S C Marks Int. J. Dev. Biol. (2001) 45: 853-859

Sperm quality in spontaneous unilateral abdominal cryptorchid boars. E Pinart, R Camps, M D Briz and S Bonet Int. J. Dev. Biol. (1996) 40: S225-S226

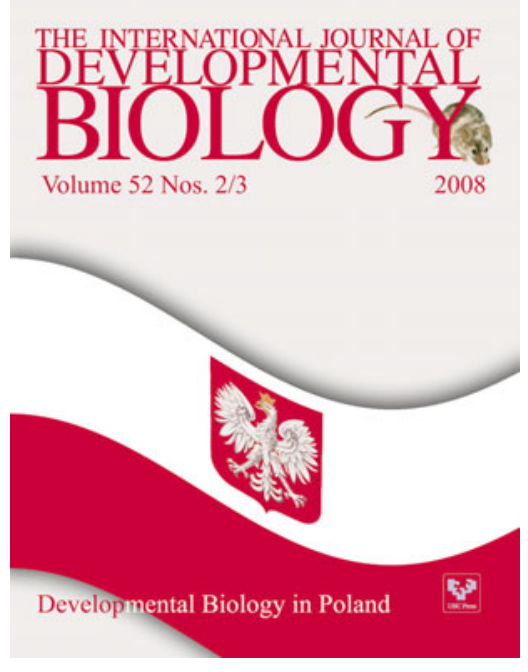

2006 ISI ${ }^{* *}$ Impact Factor $=3.577^{\star \star}$

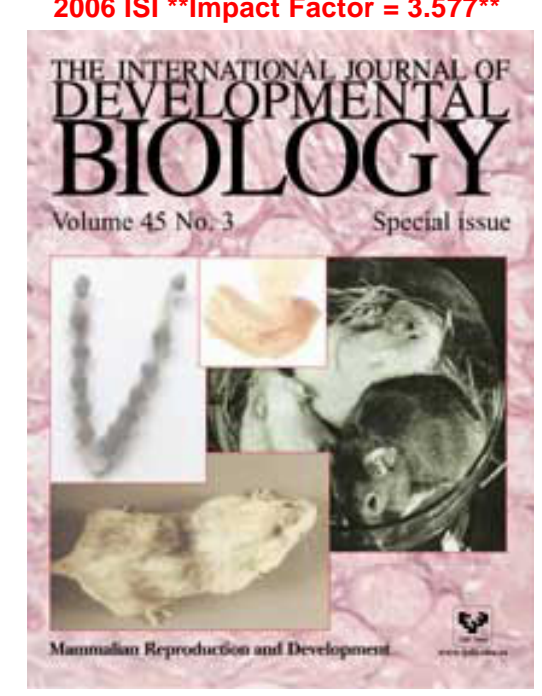

